\title{
The Impact of Rising Residential Land Cost on Divorce Rate
}

\section{Tengteng Li}

School of Economics, Jinan University, Guangzhou, China

Email: 15521177235@163.com

How to cite this paper: Li, T.T. (2018) The Impact of Rising Residential Land Cost on Divorce Rate. Open Journal of Social Sciences, 6, 168-182.

https://doi.org/10.4236/jss.2018.63012

Received: March 11, 2018

Accepted: March 25, 2018

Published: March 28, 2018

Copyright $\odot 2018$ by author and Scientific Research Publishing Inc. This work is licensed under the Creative Commons Attribution International License (CC BY 4.0).

http://creativecommons.org/licenses/by/4.0/

\begin{abstract}
Based on the data of 118 cities residential land cost and divorce rate data in China from 2008 to 2015, this paper analyzes the impact of rising residential land cost on divorce rate by using the pooled OLS model and the two-way panel fixed effect model. The divorce rate of cities with home buying restrictions is corrected due to some phenomena of fake divorce. The empirical results show that rising residential land cost significantly increases the divorce rate. For every 1 percent increase of residential land price, divorce rate increases by 0.10 thousandth. Furthermore, the impact is heterogeneous for different regions of China. The rising residential land cost significantly increases the divorce rate of eastern and central regions, with the impact in eastern region higher than that in central part, but has no significant effect on the divorce rate of the western region. The government should take measures to reduce the cost of residential land, such as strengthening the supervision of the residential land bidding, or increasing the land use planning of indemnificatory housing appropriately. Furthermore, the government can design purchase policy to further screen fake divorce or to avoid fake divorce, such as linking the purchase policy to individuals rather than family units to limit the purchase of multiple sets of real estate.
\end{abstract}

\section{Keywords}

Divorce Rate, Residential Land, Home Buying Restrictions, Regional Differences

\section{Introduction}

The family is the basic unit that constitutes society. Family stability is the basis of social stability, and conjugal relation is an important factor in maintaining 
family stability. In recent years, with the increase of population mobility, excessively rising house prices, and unbalanced sex ratio, the divorce rate in China has shown a rapid upward trend and large regional differences. Figure 1 shows the trend map of rising house price and rising divorce rate in China during 2008 to 2015. The data come from National Bureau of Statistics of China. The family structure is dramatically changing. Since the reform and opening up, the divorce rate of various provinces and cities has shown an increasing trend year by year. According to the statistics of China Civil Affairs' Statistical Yearbook, the crude divorce rate in China was $2.79 \%$ in 2015; the total number of divorces in China in 2015 was 3.841 million pairs; the total number of married couples was 12.247 million pairs. The national exit ratio was $31.36 \%$, and the exit ratio of Jilin City was even up to $52.61 \%$. China's divorce rate has changed so dramatically in a short period of time that is not only detrimental to the stability of the family and the healthy development of children, but also poses a threat to the construction of a harmonious society.

As the structure of marriage and family has changed drastically in China, China's economic structure has undergone dramatic changes, especially the rapid rise of the residential market closely related to the family. According to China Real Estate Statistics Yearbook, the total housing construction area of China in 2015 is 7356.93 million square meters, of which the residential area is 5115.70 million square meters, accounting for $69.5 \%$ of the total construction area. The average sales price of commercial housing is 6793 yuan per square meter in 2015, of which the average residential sales price is 6472 yuan per square meter. The average sales price of commercial housing is 3168 yuan per square meter in 2005, of which the average residential sales price is 2937 yuan per square meter. As the most basic and important part of housing prices, the cost of residential land is not affected by many external factors like housing prices. It is only influenced by the price of land itself and the plot ratio planned

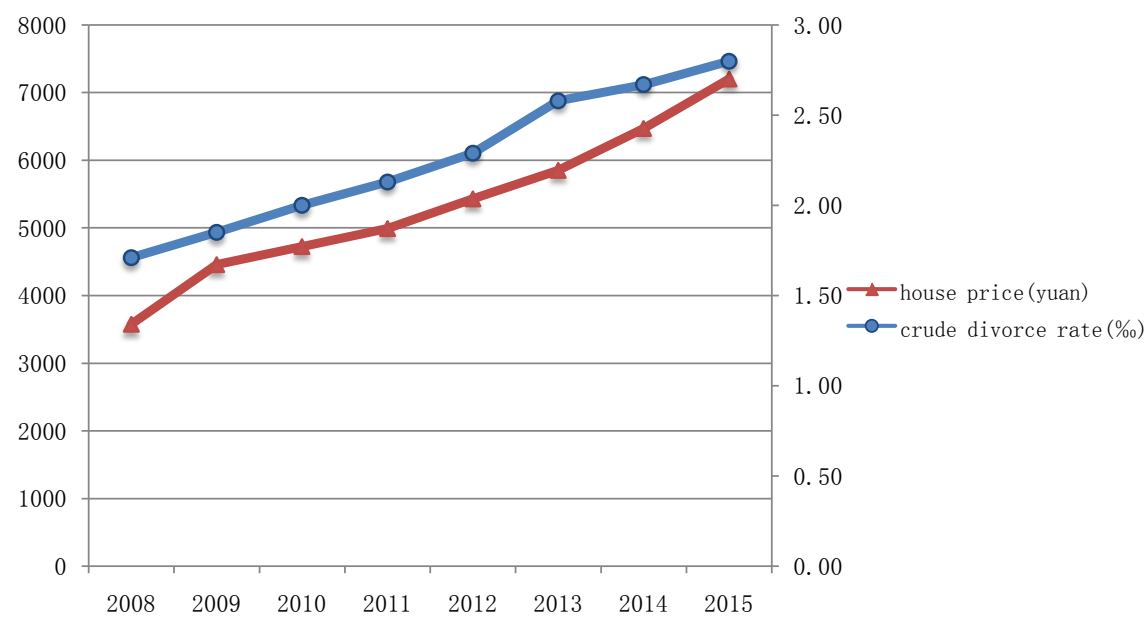

Figure 1. The trend map of rising house price and crude divorce rate in China during 2008 to 2015. 
by the government. In recent years, it has also been rising gradually. According to China Top 100 Real Estate Enterprises Research Report, the cost of land acquisition remains high for the top 100 enterprises. The average floor price of new land increases by $21.0 \%$ compared with last year in 2015. Among them, the average newly added floor price of the first-tier cities is over 14,000 yuan per square meter, up 32.0\% year-on-year growth. Qin, Zhu and Zhu (2016) [1] also argue that rising land costs have driven up housing prices to a certain extent.

Becker (1974) [2] creatively uses the economics method to analyze the family's social behavior, believing that the cost of marriage includes the transaction costs directly related to marriage and divorce and the opportunity cost of keeping singleton or marriage. Housing costs are a large part of modern marriage costs in China. Although some scholars like Kan and Lv (2015) [3] have been concerned about the impact of rising housing prices on divorce rates in China, and study the relationship between provincial housing prices and divorce rates, but because the heterogeneity of the provincial level is too broad, and housing price is affected by many factors, such as developers speculation, later construction costs and real estate purchase taxes, they do not make the mechanism clear that how the price affects divorce rate. As the most basic and important part of the housing price, the residential land cost has a more direct and clear impact on divorce rate. There are many studies about the housing market, but most of them focus on the economic impact of the housing market. No one has yet studied the impact of residential land cost on divorce rate. This paper studies the issue from the city level and uses data on urban residential land costs and divorce rates from 2008 to 2015 to explore the impact of rising residential land costs on the divorce rate. It helps provide policymakers a theoretical basis for formulating universal policies, promote family stability and harmonious social development, and mitigate the impact and harms of rising housing costs on divorce rate.

Most of the previous literatures study the factors affecting the divorce rate from the perspective of demography and sociology. There are few studies starting from the economics field, and the research on divorce is mostly confined to qualitative analysis and lack of quantitative research. This paper attempts to distinguish it from the previous literature in two aspects: 1) Based on Becker's marriage economics theory, it integrates the existing theoretical research results into empirical research, and empirically explore the impact of rising residential land cost in China on the divorce rate. 2) At present, no one has studied the impact of the residential land cost on divorce rate. This paper is a good way to isolate the part of the house price that is susceptible to external influences, to make up for the gaps in previous research and to enrich China's housing and marriage market research.

This paper is organized as follows: The second part is a literature review; The third part is the model construction and variable definition; The fourth part is the empirical results and analysis; Finally, it is the conclusion and policy suggestion of this article. 


\section{Literature Review}

\subsection{Research Summary of Factors Influencing Divorce Rate}

Marriage economics initiated by Becker argues that divorce is caused by the fact that both husband and wife find that the income of marriage is less than the sum of their income when they are single. There are mainly two reasons for the discrepancy between actual income and expected income of marriage: one is marriage match quality, the other one is income shock. Income shock affects the stability of marriage by affecting the income of both spouses. It can be divided into positive shock and negative shock. The impact of positive shock on divorce is uncertain. For example, for a family, the increase in income not only increases personal income but also increases the overall return on marriage. The former results in an increase in divorce; the later leads to a decrease in divorce. Negative shock, on the other hand, reduces the total output of households. It makes household income less than the sum of single income and leads to an increase in divorce. Weiss and Wills (1997) [4], Doiron and Mendolia (2012) [5] and Eliason (2012) [6] have all confirmed the impact of income shock. However, since the quality of marriage matching is unforeseeable in advance and the search cost is high, it will result in the mismatch of the marriage of some people. When the total output of the couple is less than the sum of the income of two couples, divorce will happen. Since the match quality is difficult to measure, academic researches use proxy variables to solve this problem, such as education level, age, religion, and ethnicity.

The western academia has formed a relatively mature system for the research on the factors that affect the divorce rate. Some domestic scholars have mainly summarized the following three explanations: First, social aggregation theory. Breault and Kposowa (1987) [7] consider a value concept convergence, good interpersonal interaction and strong social connections will lead to stable marital relations and lower the level of divorce. On the contrary, the weakening of social cohesion will lead to an increase in the divorce rate. Second is economic and social structure theory (Glick and Lin, 1986 [8]; South, 1985 [9]; Trent and South, 1989 [10]). According to the theory, the regional differences in the level of divorce depend mainly on the different economic and social characteristics of different regions and the characteristics of population structure. Third is marriage justice impact theory (Nakonezny, Shull and Rodgers, 1995) [11]. Specifically, the factors influencing the divorce rate involve many disciplines such as demography, sociology, economics, law and so on. The Chinese scholar Cheng (2010) [12] studies the factors affecting the divorce rate from various dimensions. Therefore, we sort out the international studies on population from the four aspects of population, society, economy and law, and pay attention to the interpretation of these factors using Becker's point of view of marital economics.

The first category is the population aspect. In the family life cycle theory, children play a big role in the family. Since children can be regarded as the cost to be considered when the family divorces, compared with the couples without 
children, on average, couples with children are less likely to divorce, which is in fact the same as Becker's income shock in the divorce. Xuand Ye (2002) [13] use Chinese data to analyze the regional differences in divorce rates and find that the stability of couples' marriage was mainly affected by the children they raised. Feng (2014) [14] mainly explores the impact of birth rates on the divorce rate in China and finally obtains a $\mathrm{U}$-shaped curve on the divorce rate and birth rate. Some scholars also find that the change of fertility rate can explain the regional difference of urban divorce rate. For example, Du (2010) [15] concludes that the increase of children can significantly reduce the probability of divorce. In addition, the sex ratio of the population can also directly affect the divorce rate. The imbalance of the sex ratio will directly increase the cost of the marriage search, which will affect the marriage match quality. Trent and South (1989) [10] shows that the relationship between sex ratio and divorce rate is significantly negative, but Lester (1999) [16] finds that the effect of sex ratio on divorce rates varies from country to country. For the United States, the higher the sex ratio, the higher the divorce rate. But for Switzerland, the higher the sex ratio, the lower the divorce rate. Zhang (2012) [17] and Zhang (2013) [18] find that the imbalance of sex ratios increases the bargaining power of women in the marriage market in China.

The second category is the social aspect. The level of education also affects the divorce rate. Becker, Landes and Michael (1977) [19] consider that stable marriages have the same level of education. The higher the education level, the easier it is to find a matching marriage mate, thereby improving the quality of marriage and lowering the divorce rate. This is also verified by a large number of empirical studies. Wang and Ye (2008) [20] verifies that the higher the level of education, the higher the level of marital satisfaction. Du (2010) [15] also conducts a study on micro-survey data on the labor migration and marital stability in China and finds a high female education level helps reduce the divorce rate. Many scholars study the situation of marriage and floating population and think that as the process of urbanization accelerates in China, the population in rural areas is less than before and the population of urban areas is more and more. In the process, the society is affected by the external open culture impact and the divorce rate naturally rises. For example, Du (2010) [15] and Mo and Shi (2015) [21] conduct tests using the China Nutrition and Health Survey (CHNS). Gao (2011) [22] uses village-level panel data to test and Wang and Ye (2008) [20] and Sun and Ye (2010) [23] study it as well.

The third is the economic aspect. According to Glick and Lin (1986) [8], there is a positive correlation between economic prosperity and divorce rate. The more prosperous the economy, the higher the divorce rate. This is in line with the income shock of Becker's point. Moreover, the higher the level of urbanization, the easier it is for people to come into contact with an open and diverse culture. Affected by these cultures, husbands and wives also have a more liberal view of marriage. For inappropriate marriages, it is easier for couples to break up 
and the divorce rate is relatively high. Both Cherlin (1977) [24] and Lehrer (1969) [25] find that the divorce rate is higher due to the concentration of urban population, the lower search costs for spouses and the larger market for remarriage. Meng (2000) [26] analyzes the changes of the divorce rate and urban-rural population structure in China from 1979 to 1991 using the time series analysis method. It finds that there is a significant positive correlation between the development of population urbanization and the divorce rate, and there exists five years of delay. South (1985) [9] finds a significant positive correlation between employment pressure and divorce rate in an area. Unemployment can lead to more couples divorcing. Mi (2007) [27] conducts empirical research on the data of 2000-2004 in 30 provinces and cities in China. It also finds that the higher the unemployment rate, the higher the divorce rate.

The fourth category is the legal aspect. The relaxation of the marriage law is equivalent to the positive impact of income shock. The simplification of procedures and the clarity of the regulations have reduced the cost of divorce. By constructing a spouse-matching and multiple-equilibrium model, Bac (2016) [28] finds that the decline in divorce costs has a direct divorce increase effect in the short run, and it releases some divorced couples to the remarried market. Peters (1976) [29] finds that legal systems, social norms, or cultural conventions have an impediment to divorce, and the relaxation of the marriage law will increase the divorce rate. Nakonezny, Shull and Rodgers (1995) [11] studies divorce law data from the U.S. states and finds that divorce rates varies widely from place to place because of differences in the implementation of divorce laws. Mi (2007) [27] conducts empirical research on the data of 2000-2004 in 30 provinces in China and finds that the difficulty of divorce is negatively related to the divorce rate in judicial practice.

\subsection{A Review of the Impact of Residential Land Cost on Divorce Rate}

At present, few scholars have studied the impact of residential land cost on divorce rate. Since the residential land cost is the most basic part of housing prices, and in recent years, the relationship between housing prices and divorce rate has attracted the attention of some scholars, it is necessary to know the research results and the latest progress of this research object. International studies of housing and divorce are mostly related to property consequences. Kirsten and Claus (2008) [30], Joseph and Rowlingson (2011) [31] study the results of housing divorce as a result of legal practice of property separation and child custody. However, Tang (2013) [32] notes that some limited purchase cities have seen the fake divorce phenomenon in buying houses. Kanand Lv (2015) [3] use panel data from 31 provinces and cities in China in 1999-2010 to analyze the impact of rising housing prices on divorce rates. Although the results are not significant, they find that there is a positive correlation between housing prices and divorce rates. Rising house prices in the eastern, central and western regions all raise the 
divorce rate, but only the east increases significantly. However, due to the heterogeneity of the provincial level is too broad, and prices are subject to multiple factors, they do not make the mechanism clear. Zeng and $\mathrm{Wu}$ (2000) [33] find that the divorce rate in China shows obvious geographical characteristics, mainly manifested the low rate of divorce in the eastern areas and the highest divorce rate in the northeast and northwest regions. Su, Liu and Peng (2015) [34] use spatial statistical analysis to find that there is a high divorce rate in all provinces in China. Taking the residential land cost as the most important component of housing prices into account, it is only affected by the price of the land itself and the pre-planned plot ratio of the government, and land supply planning in eastern, central, and western China is different. The land supply environment in the mid west is more relaxed than in the east, and the cost of housing is relatively low. At present, no one has studied the impact of residential land cost on the divorce rate at the city level. Therefore, this paper studies the relationship between residential land costs and divorce rates, hoping to make up for the gap in this area.

\section{Model Construction and Variable Definition}

In this paper, panel data of 118 cities in China from 2008 to 2015 are used to examine the impact of the rising residential land cost on the divorce rate. In addition, the paper investigates the different effects of divorce rates in different regions and the underlying principles. The test model is:

$$
\text { Divorce }_{i t}=\alpha_{0}+\alpha_{1} \text { Inresidence }_{i t}+\sum_{m} \beta_{m} \text { Control }_{i t}+\gamma_{i}+\varepsilon_{i t}
$$

where $i$ and $t$ represent city and year respectively. $\gamma_{i}$ represents city differences and $\varepsilon_{i t}$ represents random error terms. The explained variable Divorce $_{i t}$ is the divorce rate, which is expressed by the internationally accepted crude divorce rate. It is the number of divorce per 1000 people over a period of time, which is calculated as the annual number of divorces/annual average population * $1000 \%$. The divorce data come from the China Civil Affairs' Statistical Yearbook. Core explanatory variable Inresidence $_{i t}$ represents residential land costs, using the logarithm of residential land to express. Data come from China Index Academy database. Control ${ }_{i t}$ stands for other control variables, including per capita GDP, urbanization rate, unemployment rate, sex ratio, population density, teacher per capita. The urbanization rate $\left(u_{r b a n}{ }_{i t}\right)$ is expressed as the proportion of non-agricultural population to the total population. The unemployment rate $\left(\right.$ unemploy $_{i t}$ ) is expressed as the ratio of registered unemployed to the labor force. The sex ratio $\left(\operatorname{sex}_{i t}\right)$ is the male population/female population. The population density $\left(p d e n_{i t}\right)$ is the administrative area of each city/annual total population. The average level of education is the number of teachers per capita ( pteacher $_{i t}$ ), the number of teachers in ordinary secondary schools/average annual population. In the process of regression, this paper takes the logarithm of GDP per capita and population density. The data of control variables come from 
China City Statistical Yearbook 2016 and China Regional Economic Statistical Yearbook 2016. Descriptive statistics of the variables are shown in Table 1.

\section{Empirical Results and Analysis}

\subsection{Basic Regression Analysis}

Since the sample data in this paper are panel data, the choice of regression model can be pooled OLS, fixed effect model and random effect model. In this paper, we first use the LR test and Hausman test to judge, the results show that the fixed effect model should be used. Taking the time dimension of the sample data into account, we use the LR test to determine the time effect and find it significant. So in order to control the effect of year differences, this paper adds the time dummy variable (yr_dum). Since control the heterogeneity at the individual level helps to reduce the heteroscedasticity, the estimation model used in this paper is the panel bidirectional fixed effect model. In order to correct the influence of heteroskedasticity and autocorrelation on the coefficient estimation, this paper also performed the estimation of adding clustering robust standard errors. The basic regression results are shown in Table 2.

The regression (1) in Table 2 is the estimation of all samples using the pooled estimation model (OLS), and the rest are fixed effect model (FE) estimates. Among them, the regression (2) is the regression without adding the control variables, and the regression (4) adds the clustering robust standard error compared with regression (3). The estimated coefficient and standard error are more effective. This article mainly explains the results of panel bidirectional fixed effect models using clustering robust standard errors (Regression (4) and the following regression).

As can be seen from Table 2, the coefficients of residential land prices are significantly positive, indicating that the rising residential land cost in China has an impact on the divorce rate, and for every 1 percent increase of residential land

Table 1. Descriptive statistics of variables.

\begin{tabular}{|c|c|c|c|c|c|}
\hline Variables & Sample & Mean & $\begin{array}{l}\text { Standard } \\
\text { deviation }\end{array}$ & Minimum & Maximum \\
\hline Divorce rate (divorce) & 944 & 1.899 & 0.898 & 0.093 & 5.873 \\
\hline $\begin{array}{c}\text { The logarithm of residential land price } \\
\text { (lnresidence) }\end{array}$ & 944 & 7.756 & 0.844 & 4.656 & 11.516 \\
\hline $\begin{array}{l}\text { The logarithm of per capita GDP } \\
\text { (lnpgdp) }\end{array}$ & 944 & 10.675 & 0.580 & 8.776 & 12.003 \\
\hline Urbanization rate (urban) & 944 & 45.749 & 20.163 & 8.320 & 100.00 \\
\hline Unemployment rate (unemploy) & 944 & 5.117 & 3.227 & 0.297 & 55.991 \\
\hline Sex ratio (sex) & 944 & 1.052 & 0.296 & 0.779 & 9.988 \\
\hline $\begin{array}{c}\text { The logarithm of population density } \\
\text { (lnpden) }\end{array}$ & 944 & 6.121 & 0.723 & 4.026 & 7.894 \\
\hline $\begin{array}{c}\text { Number of teachers per person } \\
\text { (pteacher) }\end{array}$ & 944 & 0.401 & 0.090 & 0.236 & 1.273 \\
\hline
\end{tabular}


Table 2. Basic regression results.

\begin{tabular}{ccccc}
\hline \multirow{2}{*}{ Variables } & OLS & FE & FE & FE \\
\cline { 2 - 5 } & $(1)$ & $(2)$ & $(3)$ & $(4)$ \\
\hline \multirow{2}{*}{ lnresidence } & $0.130^{* * *}$ & $0.188^{* * *}$ & $0.130^{* * *}$ & $0.130^{* * *}$ \\
& $(0.033)$ & $(0.036)$ & $(0.033)$ & $(0.033)$ \\
lnpgdp & $0.681^{* * *}$ & & $0.681^{* * *}$ & $0.681^{* * *}$ \\
& $(0.054)$ & & $(0.054)$ & $(0.060)$ \\
urban & $0.011^{* * *}$ & & $0.011^{* * *}$ & $0.011^{* * *}$ \\
& $(0.001)$ & & $(0.001)$ & $(0.001)$ \\
unemploy & $0.015^{* *}$ & & $0.015^{* *}$ & $0.015^{* *}$ \\
& $(0.007)$ & & $(0.007)$ & $(0.008)$ \\
sex & -0.010 & & -0.010 & -0.010 \\
lnpden & $(0.070)$ & & $(0.070)$ & $(0.023)$ \\
& $0.387^{* * *}$ & & $0.387^{* * *}$ & $0.387^{* * *}$ \\
pteacher & $(0.034)$ & & $(0.034)$ & $(0.037)$ \\
& $-1.253^{* * *}$ & & $-1.253^{* * *}$ & $-1.253^{* * *}$ \\
constant & $(0.256)$ & & $(0.256)$ & $(0.348)$ \\
yr_dum & $-4.274^{* * *}$ & -0.023 & $-4.274^{* * *}$ & $-4.274^{* * *}$ \\
N & $(0.524)$ & $(0.275)$ & $(0.524)$ & $(0.521)$ \\
R2 & Control & Control & Control & Control \\
\hline
\end{tabular}

a. The values in brackets are all standard errors of clustering. ${ }^{*},{ }^{* *}$, and ${ }^{* * *}$ are statistically significant at the significance levels of $10 \%, 5 \%$, and $1 \%$, respectively.

price, divorce rate increases by 0.13 thousandth. The per capita GDP has a significantly positive effect on the divorce rate. This is because the higher the per capita GDP, the more individual's income, and the relative less income from marriage, the higher the divorce rate. The effect of urbanization rate on the divorce rate is significantly positive because the higher the level of urbanization, the greater influence of open cultural thoughts on family values. The higher mobility of urban population also provides more marriage options and reduces remarriage costs, so the divorce rate increases. The coefficient of unemployment rate is significantly positive, which is consistent with Becker's marriage economics. It believes that the high unemployment rate has a negative impact on household income. Although the impact of sex ratio on the divorce rate is negative, it is not significant. The impact of population density on the divorce rate is significantly positive, because the greater the population density, the more potential candidates for the marriage market, the lower the cost of search for spouses, and the higher divorce rate. The educational level has a significant negative effect on the divorce rate, indicating that the higher the average level of education, the lower the divorce rate. The higher the level of education, the more reasonable people will be when choosing a spouse, and the lower the probability of a marriage mismatch, and thus less divorce.

\subsection{Test of Differentiating "True Divorce"}

Since the rising residential land cost and housing prices have brought a series of 
adverse effects, China has put off many restrictions on purchase policies to control the housing market and curb the trend of excessive housing prices in some big cities from 2010. For example, the "State Article 11" promulgated on January 10, 2010 and the "New State Ten Articles" promulgated on April 17 that year increase the payment interest rate in addition to the payment ratio for households purchasing the second suite. The "New State Eight" promulgated on January 26, 2011links the purchase and hukou to make the purchase conditions more stringent. By the end of 2011, a total of 46 cities across the country had implemented home buying restrictions. However, the home buying restriction staking the family as a censoring agency have caused many families to loophole in their policies and evade the impact of the restriction through fake divorce. These families usually achieve the goal of real buying a house through fake divorce. They also save a large sum of payment and interest rate before they remarried. Therefore, the direct use of all the divorced couples as an explanatory variable, the results for the city with home buying restrictions should be high, because many cities have a serious fake divorce situation. Since we cannot accurately know whether divorce decisions made by families are true divorce, we cannot draw the most accurate coefficient. Fortunately, China Civil Affairs' Statistical Yearbook not only counts the number of divorces in each region, but also counts the number of people who remarry. Although part of the remarriage is due to the return of feelings and the desire to make up for the divorce consequences of previous impulses, it is safe to say that the overwhelming majority of couples who really buy a house are going to remarry. Therefore, this paper goes on to amend the method of calculating the divorce rate of the cities, using the total number of divorced couples minus the remarriage couples as the true divorce, and calculate the true divorce rate relative to the crude divorce rate. The divorce rate in non-restricted cities still adopts the crude divorce rate, and the same regression is performed on all the samples before using all the variables. The regression test results are shown in Table 3.

As can be seen from Table 3, after removing the possible fake divorce in urban areas, the coefficient of residential land price is still significantly positive, and the coefficient is smaller than the direct regression results for all samples with rough divorce rate. This shows that the increase of the residential land cost in China indeed has an impact on the true divorce rate. For every 1 percent increase of residential land price, divorce rate increases by 0.10 thousandth. The results of the control variables are still consistent with Table 2, the higher the per capita GDP, the higher the urbanization rate, the higher the unemployment rate and the higher the population density, the higher the divorce rate. The sex ratio has no significant effect on the true divorce rate, and the education level has a significant negative effect on the true divorce rate.

\subsection{Divided Regional Eastern and Western Regional Differences Test}

Through the previous regression model and estimation results, this paper 
Table 3. Test of the residential land cost on true divorce rate.

\begin{tabular}{ccccc}
\hline \multirow{2}{*}{ Variables } & OLS & FE & FE & FE \\
\cline { 2 - 5 } & $(5)$ & $(6)$ & $(7)$ & $(8)$ \\
\hline \multirow{2}{*}{ Inresidence } & $0.100^{* * *}$ & $0.151^{* * *}$ & $0.100^{* * *}$ & $0.100^{* * *}$ \\
& $(0.030)$ & $(0.031)$ & $(0.030)$ & $(0.028)$ \\
lnpgdp & $0.607^{* * *}$ & & $0.607^{* * *}$ & $0.607^{* * *}$ \\
& $(0.047)$ & & $(0.047)$ & $(0.051)$ \\
urban & $0.008^{* * *}$ & & $0.008^{* * *}$ & $0.008^{* * *}$ \\
& $(0.001)$ & & $(0.001)$ & $(0.001)$ \\
unemploy & $0.009^{* *}$ & & $0.009^{* *}$ & $0.009^{* *}$ \\
& $(0.006)$ & & $(0.006)$ & $(0.007)$ \\
sex & -0.026 & & -0.026 & -0.026 \\
lnpden & $(0.061)$ & & $(0.061)$ & $(0.023)$ \\
& $0.341^{* * *}$ & & $0.341^{* * *}$ & $0.341^{* * *}$ \\
pteacher & $(0.031)$ & & $(0.031)$ & $(0.033)$ \\
& $-0.931^{* * *}$ & & $-0.931^{* * *}$ & $-0.931^{* * *}$ \\
constant & $(0.226)$ & & $(0.226)$ & $(0.292)$ \\
yr_dum & $-3.669^{* * *}$ & 0.113 & $-3.669^{* * *}$ & $-3.669^{* * *}$ \\
N & $(0.463)$ & $(0.233)$ & $(0.463)$ & $(0.438)$ \\
R2 & Control & Control & Control & Control \\
\hline
\end{tabular}

a. The values in brackets are all standard errors of clustering. ${ }^{*}{ }^{* *}$, and ${ }^{* *}$ are statistically significant at the significance levels of $10 \%, 5 \%$, and $1 \%$, respectively.

verifies that the rising residential land cost will indeed impact the divorce rate, and the higher the residential land cost, the higher the divorce rate. Due to the different land supply plans in the eastern, central and western parts of China, the land supply environment in the western part is relatively more relaxed than the eastern and central parts, so the cost of housing is relatively lower. In order to test whether the rising residential land cost in the three eastern, central and western regions will have a heterogeneous impact on the divorce rate, this paper divides 118 cities into three regions: eastern, western and central China. The results of regional grouping regression are shown in Table 4.

The results of the crude divorce rate test for all the samples show (regression (9) (10) (11)) that the increase in the residential land cost significantly increases the divorce rate in the eastern and central regions, but there is no significant effect on the western region. And the impact in eastern China is significantly greater than the central. This is in line with expectation. The residential land resources are in a strained condition and the pressure on housing cost is greater in the eastern region. Therefore, the impact on the divorce rate will be relatively greater. After the revision of the divorce rate in the restricted city, the test results of the true divorce rate for all samples are also shown (regression (12) (13) (14)). The coefficient of residential land price is significantly positive for the eastern and central regions. There is no significant impact in the western region. These results verify the heterogeneity of the divorce rate caused by the rising residential land cost in different regions in China. Among them, the rising residential 
Table 4. Regional grouping test of the residential land cost on divorce rate.

\begin{tabular}{ccccccc}
\hline \multirow{2}{*}{ Variables } & \multicolumn{3}{c}{ Crude divorce rate } & \multicolumn{3}{c}{ True divorce rate } \\
\cline { 2 - 7 } & eastern & central & western & eastern & central & western \\
\cline { 2 - 6 } & $(9)$ & $(10)$ & $(11)$ & $(12)$ & $(13)$ & $(14)$ \\
\hline \multirow{2}{*}{ Inresidence } & $0.230^{* * *}$ & $0.157^{* * *}$ & 0.089 & $0.175^{* * *}$ & $0.117^{* * *}$ & 0.085 \\
& $(0.039)$ & $(0.044)$ & $(0.089)$ & $(0.034)$ & $(0.038)$ & $(0.082)$ \\
lnpgdp & $0.808^{* * *}$ & $0.955^{* * *}$ & 0.065 & $0.718^{* * *}$ & $0.847^{* * *}$ & 0.053 \\
& $(0.058)$ & $(0.067)$ & $(0.183)$ & $(0.048)$ & $(0.054)$ & $(0.161)$ \\
urban & $0.011^{* * *}$ & $0.004^{* * *}$ & $0.022^{* * *}$ & $0.008^{* * *}$ & $0.003^{* * *}$ & $0.019^{* * *}$ \\
& $(0.001)$ & $(0.002)$ & $(0.006)$ & $(0.001)$ & $(0.002)$ & $(0.005)$ \\
unemploy & $0.029^{* *}$ & $0.026^{* *}$ & $-0.029^{*}$ & $0.022^{* *}$ & $0.021^{* *}$ & $-0.029^{* *}$ \\
& $(0.014)$ & $(0.011)$ & $(0.015)$ & $(0.012)$ & $(0.009)$ & $(0.014)$ \\
sex & 0.011 & 0.115 & $-8.720^{* * *}$ & -0.008 & -0.624 & $-7.542^{* * *}$ \\
& $(0.013)$ & $(0.708)$ & $(2.445)$ & $(0.011)$ & $(0.613)$ & $(2.119)$ \\
lnpden & $0.701^{* * *}$ & $0.007^{* *}$ & $0.252^{* * *}$ & $0.589^{* * *}$ & $0.093^{* *}$ & $0.274^{* * *}$ \\
& $(0.047)$ & $(0.047)$ & $(0.095)$ & $(0.040)$ & $(0.039)$ & $(0.086)$ \\
pteacher & $-0.712^{* *}$ & $-1.994^{* * *}$ & 1.554 & $-0.455^{* *}$ & $-1.958^{* * *}$ & 1.936 \\
& $(0.354)$ & $(0.487)$ & $(1.483)$ & $(0.294)$ & $(0.423)$ & $(1.314)$ \\
constant & $-4.833^{* * *}$ & $-8.955^{* * *}$ & $6.888^{*}$ & $-4.201^{* * *}$ & $-6.401^{* * *}$ & $5.493^{*}$ \\
& $(0.607)$ & $(1.188)$ & $(3.524)$ & $(0.503)$ & $(0.963)$ & $(3.127)$ \\
yr_dum & Control & Control & Control & Control & Control & Control \\
& & & & & & \\
N & 568 & 232 & 144 & 549 & 232 & 143 \\
R2 & 0.631 & 0.728 & 0.582 & 0.622 & 0.733 & 0.572 \\
\hline
\end{tabular}

a. The values in brackets are all standard errors of clustering. ${ }^{*}{ }^{* *}$, and ${ }^{* * *}$ are statistically significant at the significance levels of $10 \%, 5 \%$, and $1 \%$, respectively.

land cost has the most significant impact on the divorce rate in the eastern region, followed by the divorce rate in the central region, and no significant impact on the divorce rate in the western region.

\section{Conclusion and Policy Suggestions}

Based on the data of China's residential land cost and divorce rate from 2008 to 2015, this paper investigates the impact of the rising residential land cost on the divorce rate using the pooled OLS model and the two-way panel fixed effect model. The divorce rate of cities with home buying restrictions is corrected due to some phenomena of fake divorce. At the same time, this paper also analyzes the heterogeneity of the residential land cost on the divorce rate in different regions of China. The results of the study show that the increase in the residential land cost in China has indeed significantly increased the divorce rate, and that for every $1 \%$ rise in residential land price, the divorce rate increases by $0.10 \%$. Tests that distinguish eastern, central and western regions find that the rising residential land cost increases the divorce rate significantly in the eastern and central regions but has no significant effect on the divorce rate in the western region. However, there are some limitations about this research. Due to the lack of data on residential land cost in some cities, the study sample for this research is only 118 cities in China. The conclusions can become more convincing only after the data of other cities are completed. Moreover, this paper does not test the 
endogenous problem between the rising residential land cost and rising divorce rate. If there exists endogenous problem, the research should find a good instrument variable to resolve it. These are some limitations of the research in this paper. Later scholars can further explore and improve this research. The conclusion of this paper has important policy implications.

The continuous rise of the residential land cost makes such a huge change in the divorce rate in China within a short period of time, which is not only unfavorable to the stability of the family and the healthy development of children, but also threatens the building of a harmonious society. This should arouse the widespread concern of relevant departments. First of all, the government should take measures to reduce the cost of residential land. It can strengthen the supervision of bidding for construction of residential land, prevent some companies from cooperating privately and drive up land prices. It can also appropriately increase the affordable housing land planning, to reduce purchase costs from the source. In addition, some fake divorce phenomena in city with home buying restrictions actually result from the design of the country's purchase restriction policy. Some families have circumvented the influence of the purchase restriction policy by changing the marital status. Under the existing legal and institutional framework, there are no effective measures to prevent such distorted behavior. Therefore, instead of restricting the purchase of multiple properties on the family as a unit, the government may consider designing a restriction policy that further identifies fake divorce or avoids fake divorce. On one hand, it can promote the implementation of the government's policies, and on the other hand, it also mitigates the adverse impact of the high divorce rate on families and society.

\section{References}

[1] Qin, Y., Zhu, H. and Zhu, R. (2016) Changes in the Distribution of Land Prices in Urban China during 2007-2012. Regional Science \& Urban Economics, 57, 77-90. https://doi.org/10.1016/j.regsciurbeco.2016.02.002

[2] Becker, G.S. (1974) A Theory of Marriage. The Economic Approach to Human Behavior, 36, 119-133.

[3] Kan, D. and Lv, L. (2015) Does Chinese Housing Prices Really Rise Divorce Rate-An Empirical Study Based on Provincial Panel Data. Journal of Guizhou University of Finance and Economics, 33, 16-24.

[4] Weiss, Y. and Willis, R.J. (1997) Match Quality, New Information, and Marital Dissolution. Journal of Labor Economics, 15, 293-329. https://doi.org/10.1086/209864

[5] Doiron, D. and Mendolia, S. (2012) The Impact of Job Loss on Family Dissolution. Journal of Population Economics, 25, 367-398. https://doi.org/10.1007/s00148-010-0353-5

[6] Eliason, M. (2012) Lost Jobs, Broken Marriages. Journal of Population Economics, 25, 1365-1397. https://doi.org/10.1007/s00148-011-0394-4

[7] Breault, K.D. and Kposowa, A.J. (1987) Explaining Divorce in the United States: A Study of 3111 Counties, 1980. Journal of Marriage \& the Family, 49, 549-558. 
https://doi.org/10.2307/352200

[8] Glick, P.C. and Lin, S. (1986) Recent Changes in Divorce and Remarriage. Journal of Marriage \& Family, 48, 737-747. https://doi.org/10.2307/352566

[9] South, S.J. (1985) Economic Conditions and the Divorce Rate: A Time-series Analysis of the Postwar United States. Journal of Marriage \& Family, 47, 31-41. https://doi.org/10.2307/352066

[10] Trent, K. and South, S.J. (1989) Structural Determinants of the Divorce Rate: A Cross-Societal Analysis. Journal of Marriage \& Family, 51, 391-404. https://doi.org/10.2307/352502

[11] Nakonezny, P.A., Shull, R.D. and Rodgers, J.L. (1995) The Effect of No-Fault Divorce Law on the Divorce Rate across the 50 States and Its Relation to Income, Education, and Religiosity. Journal of Marriage \& Family, 57, 477-488. https://doi.org/10.2307/353700

[12] Cheng, M. (2010) The Research on the Influencing Factors of Divorce Rates in China. Ph.D. Thesis, Tsinghua University, Beijing.

[13] Xu, A. and Ye, W. (2002) An Analysis of China's Provincial Differences in Divorce Rates. Population Research, 26, 28-35.

[14] Feng, H. (2014) Analysis of the Effect of Birth Rate on Divorce Rate-Based on the Special Analysis Perspective of Chinese Data. Ph.D. Thesis, Fudan University, Shanghai.

[15] Du, F. (2010) The Effect of Labor Mobility in Urban and Rural Areas of China on Marital Stability. Comparative Economic \& Social Systems, No. 5, 105-112.

[16] Lester, D. (1999) Regional Differences in Divorce Rates. Journal of Divorce \& Remarriage, 30, 121-124. https://doi.org/10.1300/J087v30n03_08

[17] Zhang, Y. (2012) Sex Ratio Imbalance and Changes in Chinese Marriage Matching Pattern (1952-2006). Ph.D. Thesis, Fudan University, Shanghai.

[18] Zhang, H. (2013) Gender Imbalance, Female Family and Labor Market Bargaining Power. Ph.D. Thesis, Fudan University, Shanghai.

[19] Becker, G.S., Landes, E.M. and Michael, R.T. (1977) An Economic Analysis of Marital Instability. Journal of Political Economy, 85, 1141-1187. https://doi.org/10.1086/260631

[20] Wang, L. and Ye, W. (2008) Empirical Analysis on Marital Satisfaction of Floating Population. Population Journal, No. 2, 32-37.

[21] Mo, W. and Shi, J. (2015) The Effect of Rural Population Movement on Divorce Rate. Chinese Journal of Population Science, No. 5, 104-112.

[22] Gao, M. (2011) Rural Divorce Rate and Outbound Employment: A Study Based on Village Panel Data from 2003 to 2009 in China. The Journal of World Economy, No. 10, 55-69.

[23] Sun, Q. and Ye, W. (2010) Retrospect and Prospect for the Domestic and Foreign Research in Floating Population's Marriage and Childbirth. Population and Development, 16, 104-109.

[24] Cherlin, A. (1977) The Effect of Children on Marital Dissolution. Demography, 14, 265-272. https://doi.org/10.2307/2060785

[25] Lehrer, E.L. (1969) The Determinants of Marital Stability: A Comparative Analysis of First and Higher-Order Marriages. Research in Population Economics, 8, 91-121.

[26] Meng, Q. (2000) An Analysis of the Divorce Rate and Social Structure Change in China. Population Journal, No. 4, 53-55+59. 
[27] Mi, D. (2007) Empirical Analysis of the Factors Influencing the Divorce Rate in China. Population and Development, No. 6, 255-260.

[28] Bac, M. (2016) The Expectation Effect of a Fall in Divorce Costs. International Review of Law \& Economics, 47, 41-47. https://doi.org/10.1016/j.irle.2016.04.003

[29] Peters, J.F. (1976) Divorce in Canada: A Demographic Profile. Journal of Comparative Family Studies, 7, 335-349.

[30] Gram-Hanssen, K. and Bech-Danielsen, C. (2008) Home Dissolution: What Happens after Separation? Housing Studies, 23, 507-522. https://doi.org/10.1080/02673030802020635

[31] Joseph, R. and Rowlingson, K. (2012) Her House, His Pension? The Division of Assets among (Ex-)Couples and the Role of Policy. Social Policy \& Society, 11, 69-80. https://doi.org/10.1017/S147474641100042X

[32] Tang, Y. (2013) Why Did Divorce Rate Go with House Prices? Market Modernization, No. 31, 56.

[33] Zeng, Y. and Wu, D. (2000) Regional Analysis of Divorce in China since 1980. Demography, 37, 215-219.

[34] Su, L., Liu, Y. and Peng, X. (2015) Analysis of Spatial Aggregation and Temporal Evolution of Divorce Rate in Chinese Provinces. Population Research, 39, 74-84. 